THE FAMILY AND PUBLIC POLICY

Frank F. Furstenberg, Jr., and Andrew J. Cherlin

General Editors 



\title{
The Time Divide
}

\author{
Work, Family, \\ and Gender Inequality
}

\author{
Jerry A. Jacobs \\ Kathleen Gerson
}

HARVARD UNIVERSITY PRESS

Cambridge, Massachusetts

London, England · 2004 
Copyright (C 2004 by the President and Fellows of Harvard College

All rights reserved

Printed in the United States of America

\section{Library of Congress Cataloging-in-Publication Data}

Jacobs, Jerry A., 1955-

The time divide : work, family, and gender inequality / Jerry A. Jacobs, Kathleen Gerson.

p. cm.- (The family and public policy)

Includes bibliographical references and index.

ISBN 0-674-01153-8 (alk. paper)

1. Work and family-United States. 2. Hours of labor-United States. 3. Professional employees_-United States. 4. Women employees-United States. 5. Working class-United States. I. Gerson, Kathleen. II. Title. III. Series.

HD4904.25.J3 2004

$331.12^{\prime} 042^{\prime} 0973-\mathrm{dc} 22 \quad 2003056839$ 
To Madeleine and Elizabeth (JAJ)

To Emily (KG) 
